Nig. J. Biotech. Vol. 38 (2) : 92-100 (Dec 2021)

ISSN: 01891731

Available online at

http://www.ajol.info/index.php/njb/index

and www.biotechsocietynigeria.org

DOI: https://dx.doi.org/10.4314/njb.v38i2.10

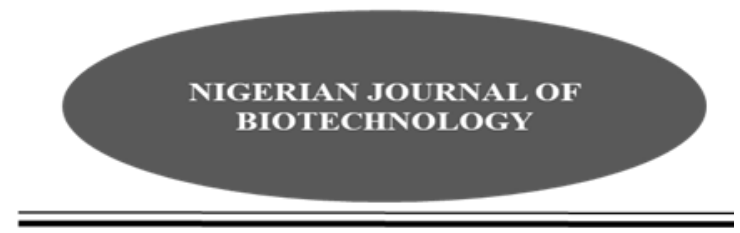

\title{
Optimizing the Effect of pH and Temperature on Atrazine Degradation by Bacillus safensis strain BUK_BCH_BTE6 an Efficient Atrazine Tolerating Bacteria from an Agricultural Soil in Kura Local Government Area of Kano State, Nigeria
}

\author{
Muhammad, F., Yusuf, F., Ahmad, F. A., Shehu, U., Yakasai, H. M. * \\ Department of Biochemistry, College of Health Sciences, Bayero University, Kano, PMB 3011, Kano \\ Nigeria.
}

\begin{abstract}
s
The widespread and long term use of atrazine results in high residue levels of atrazine in soil, which further causes water contamination, it is considered as an endocrine disruptor and is potentially carcinogenic. Microbial degradation of herbicide represents a time cost effective way of eco-restoration. This research was aimed at isolating and characterizing bacteria capable of degrading and utilizing atrazine as a sole carbon source. An enrichment method was used to isolate the bacteria on mineral salt media (MSM) following serial dilution. The isolate was identified morphologically, biochemically and molecularly as Bacillus safensis strain BUK_BCH_BTE6 based on 16S rRNA gene sequence and molecular phylogenetic analysis. The effect of $\mathrm{pH}$ and temperature on the degradation of atrazine was studied in MSM medium supplemented with atrazine as sole carbon source. Growth and degradation of atrazine in this isolate was optimal at pH 7.5 and temperature of $35^{\circ} \mathrm{C}$. Bacillus safensis is highly efficient in atrazine degradation with an optimum range of $\mathrm{pH}$ and temperature. Bacillus safensis could be a suitable candidate for bioremediation of atrazine polluted sites.
\end{abstract}

Keywords: Atrazine, Degradation, $\mathrm{pH}$, Temperature, Bacteria.

*Corresponding author: hmyakasai.bch@buk.edu.ng, +234(0)8034966925

\section{Introduction}

Worldwide, several anthropogenic activities have resulted in high increase of environmental pollution, and its effect has affect almost all components of the ecosystem (Izabel et al., 2020). Soil, as an important constituent of the terrestrial ecosystem is exposed to pollution from various sources, including industrialization and various agricultural practices. Different forms of anthropogenic pollutant entering the soil causing a very serious impact and risk to human health and terrestrial ecosystem (Sayara and Sánchez, 2020). High growth in demand and use of agricultural and industrial products have lead to rapid increases in polluted soils and waters (Zhao et al., 2018).

\section{Atrazine}

(2-chloro-4-ethylamino-6isopropylamino-1, 3, 5- triazine) is a s-triazine herbicide with a molecular formula $\mathrm{C}_{8} \mathrm{H}_{14} \mathrm{C}_{1} \mathrm{~N}_{5}(\mathrm{He}$ et al., 2019). It is a nonpolar, nonvolatile and low soluble compound (Olu-arotiowa et al., 2019). It is powdery white substance that is unstable at high temperature. It has a melting point of $173-$ $175^{\circ} \mathrm{C}$, and a boiling point of $200^{\circ} \mathrm{C}$. it solubility in water is $33 \mathrm{mgL}^{-1}$ at $20^{\circ} \mathrm{C}$, it is very soluble in organic solvents (Ariole and Abubakar, 2015). Atrazine is usually detected in the earth surface water and groundwater system because of it long half-life that ranges from $13-261$ days (Li et al., 2019). Atrazine can restrain and remove broadleaf weeds and some grass weeds that affect crop growth, and also inhibit some perennial weeds (He et al., 2019). It is also 
applied to soil as herbicide on crops such as sorghum, maize, sugarcane, ornamental plants and also applied to forests as well. It's considered among the top used herbicide in the world due to its low cost and effectiveness (Shamsedini, 2015). Atrazine is considered as a precedence pollutant that is toxic and carcinogenic. It is toxic when inhale, taken orally or excess exposure with the skin. likewise many studies on it toxicity reported atrazine to exhibit long term effect on reproductive and endocrine system, epidemiological effect to decrease sperm counts in men and is assume to be human carcinogen that lead to breast and ovarian cancer (Oluarotiowa et al., 2019).

Previous research reported various bacteria capable of atrazine biodegradation. isolation of microorganisms with high atrazine tolerance and degradation is critically needed to reduce it adverse effects on human health and ecosystem (Shiri, 2016). This paper reports the efficiency of Bacillus safensis strain BUK_BCH_BTE6 in the degradation of atrazine in MSM media.

\section{Materials and Methods}

\section{Samples Collection}

Soil profiles of $1-30 \mathrm{~cm}$ under the surface were sampled using a sterile scoop after removal of the top layer of the soil up to $1-5 \mathrm{~cm}$. Three soil samples were collected from agricultural soil in Kura Local Government Area of Kano state located between latitudes 1003' and 120 37' North and longitudes 703' and $905^{\prime}$ East of the Greenwich meridian (Ayodele, 2016). All samples were transferred to sterile polyethene bags, transported to the Microbiology laboratory in Bayero University Kano for analyses. The samples were dried, homogenized and passed through a $2 \mathrm{~mm}$ sieve. Atrazine used was of analytical grade with $90 \%$ purity.

\section{Enrichment and Isolation of Atrazine Tolerating and Degrading Bacteria}

The atrazine tolerating and degrading bacteria were isolated using culture enrichment method. The mineral salt medium contained $(\mathrm{g} / \mathrm{L}$ of distilled water): $0.5 \mathrm{gL}^{-1}$ of $\mathrm{KH}_{2} \mathrm{PO}_{4}, 3.0 \mathrm{gL}^{-1}$ of $\mathrm{K}_{2} \mathrm{HPO}_{4}, 0.2 \mathrm{gL}^{-1}$ of $\mathrm{MgSO}_{4} \cdot 7 \mathrm{H}_{2} \mathrm{O}, 0.5 \mathrm{gL}^{-1}$ of $\mathrm{NaCl}$, and $1 \mathrm{mLL}^{-1}$ of trace element concentrate solution according to Sawangjit (2016). Trace element concentrate solution had the following composition: $\mathrm{FeSO}_{4} \cdot 7 \mathrm{H}_{2} \mathrm{O}, 1 \mathrm{gL}^{-1}, \mathrm{ZnSO}_{4} \cdot 7 \mathrm{H}_{2} \mathrm{O}, 5$
$\mathrm{gL}^{-1} \mathrm{CuSO}_{4} \cdot 5 \mathrm{H}_{2} \mathrm{O}, 0.4 \mathrm{gL}^{-1}, \mathrm{MnSO}_{4} \cdot \mathrm{H}_{2} \mathrm{O}, 1 \mathrm{gL}^{-1}$, EDTA, $2.5 \mathrm{gL}^{-1}, \mathrm{Na}_{2} \mathrm{MoO}_{4} \cdot 2 \mathrm{H}_{2} \mathrm{O}, 0.25 \mathrm{gL}^{-1}$, and $\mathrm{Na}_{2} \mathrm{~B}_{4} \mathrm{O}_{7} \cdot 10 \mathrm{H}_{2} \mathrm{O}, 0.2 \mathrm{~g}$. All contents were dissolved in $1 \mathrm{~L}$ distilled water, heated to dissolve and sterilize by autoclaving for 15 minutes at 121 ${ }^{\circ} \mathrm{C}$ (Macwilliams, 2016).

A total of $10 \mathrm{~g}$ of each sample was initially inoculated and homogenized in $250 \mathrm{ml}$ Erlenmeyer flasks containing $100 \mathrm{ml}$ of mineral salt media and was supplemented with $10 \mathrm{ml}$ of atrazine as sole carbon source at a final concentration of $100 \mathrm{mg} \mathrm{L}^{-1}$. The flasks were then incubated under orbital agitation (150 rpm) at 37 ${ }^{\circ} \mathrm{C}$. After 7 days, a $10 \mathrm{ml}$ aliquot of each culture was transferred to new MSM broth $(100 \mathrm{~mL})$ with same atrazine volume. Subsequently, each culture was serially diluted from $10^{-1}$ to $10^{-6}$ in sterile distilled water and proper dilutions $10^{-6}$ was plated on MSM agar, supplemented with 0.1 $\mathrm{mL}$ of atrazine $\left(100 \mathrm{mgL}^{-1}\right)$. The Petri dish was then incubated at $37^{\circ} \mathrm{C}$ for 48 hours (Wang et al., 2015).

\section{Effect of Initial pH on Atrazine Degradation}

The effect of pH ranges: 5.5, 6.5, 7.0, 7.5, 8.0, and 8.5 was assessed. Mineral salt medium (50 $\mathrm{ml}$ ) was introduced into conical flask, $100 \mu \mathrm{L}$ of bacterial culture was used and supplemented with $100 \mu \mathrm{L}$ of atrazine with initial concentration of $100 \mathrm{mgL}^{-1}$ and incubated at $37^{\circ} \mathrm{C}$ for 120 hours. Bacterial aliquot $(1 \mathrm{ml})$ was taken after every 24 hours to measure the $\mathrm{OD}_{600}$ for bacterial growth (Mansee et al., 2017).

\section{Effect of Temperature on Atrazine Degradation}

The effect of temperature ranges was assessed. $50 \mathrm{ml}$ of Mineral salt medium was introduced into conical flask, $100 \mu \mathrm{L}$ of bacterial culture was used and supplemented with $100 \mu \mathrm{L}$ of atrazine with initial concentration of $100 \mathrm{mgL}^{-1}$ and incubated at different temperature ranges: $25^{\circ} \mathrm{C}, 30^{\circ} \mathrm{C}, 35$ ${ }^{\circ} \mathrm{C}, 40{ }^{\circ} \mathrm{C}, 45^{\circ} \mathrm{C}$, and $50^{\circ} \mathrm{C}$ for 120 hours. Bacterial aliquot $(1 \mathrm{ml})$ was taken after every 24 hours to measure the $\mathrm{OD}_{600}$ for bacterial growth (Ariole and Abubakar, 2015).

\section{Results}

Isolation, Identification and Screening of Atrazine-Degrading Bacteria

After inoculation of the culture with MSM agar and incubating at $37^{\circ} \mathrm{C}$ for 48 hours and further 
sub culturing for 24 hours at $37^{\circ} \mathrm{C}$ resulted in the appearance of white, round, slimy shape colonies with raised elevation and rough edge which look like fried egg.
Based on Morphological identification (Table 1), it was found that after visualization under light microscope, the isolates were all gram positive and rod shape with one cocci.

Table 1: Morphological Identification of the Isolate

\begin{tabular}{llll}
\hline Isolate & Gram Reaction & Shape & Colour \\
\hline$A_{1}$ & Positive & Rod & Purple \\
$A_{2}$ & Positive & Rod & Purple \\
$B_{1}$ & Positive & Rod & Purple \\
$B_{2}$ & Positive & Cocci & Purple \\
$C_{1}$ & Positive & Rod & Purple \\
$C_{2}$ & Positive & Rod & Purple \\
\hline
\end{tabular}

A total of six isolates were isolated from the atrazine contaminated soil samples, five were able to partially tolerate the varying concentrations $\left(500 \mathrm{mgL}^{-1}, 1000 \mathrm{mgL}^{-1}\right.$ and 1500 $\mathrm{mgL}^{-1}$ ) of atrazine (Table 2). Only one isolate tolerates all the concentrations of atrazine after 120 hours of incubation and therefore was used for the main study. The bacterium was identified to it generic level according to it characteristics, that may include morphological and physiological.

Table 2: Screening/Tolerance Test for Atrazine-Degrading Bacteria Grown in MSM after 48 Hours of Incubation at $37^{\circ} \mathrm{C}$

\begin{tabular}{llll}
\hline Isolate & $\mathbf{5 0 0} \mathbf{~} \mathbf{~ g L}$ & $\mathbf{1 0 0 0} \mathbf{~} \mathbf{~ g L}^{\mathbf{- 1}}$ & $\mathbf{1 5 0 0} \mathbf{~ m g L}^{-\mathbf{1}}$ \\
\hline $\mathrm{A} 1$ & + & + & - \\
$\mathrm{A} 2$ & + & - & - \\
$\mathrm{B} 1$ & + & + & + \\
$\mathrm{B} 2$ & + & + & - \\
$\mathrm{C} 1$ & - & - & - \\
$\mathrm{C} 2$ & + & - & - \\
\hline
\end{tabular}

Biochemical test for the isolate (Table 3), indicated that the isolate is positive for catalase test, oxidase test, Voges-Prauskauer test and nitrate reduction test, while negative for citrate utilization test, starch hydrolysis test, methyl red test, $\mathrm{H}_{2} \mathrm{~S}$ production test, indole production test and urease production test. 
Muhammad et al. / Nig. J. Biotech. Vol. 38 Num. 2 : 92-100 (December 2021)

Table 3: Biochemical tests for the candidate isolate $\left(B_{1}\right)$ used for characterization and degradation study

\begin{tabular}{lcc}
\hline Biochemical Test & Result \\
\hline Methyl Red & + \\
$\mathrm{H}_{2}$ S Production & + \\
Indole Production & + \\
Citrate Utilization & + \\
Starch Hydrolysis & + \\
Urea Production & - \\
Catalase & - \\
Oxidase & - \\
Voges-Prauskauer & - \\
Nitrate Reduction & -
\end{tabular}

Keys: + =Positive, =Negative

Molecular identification of the isolate was presented in Figure 1. It was found that after subjecting the PCR product to sequencing using cycle sequencing kit genetic analyzer from both forward and reverse directions. The 16S rRNA gene sequences of the bacterium obtained was compared with GenBank database using Blast Server at NCBI. The analysis show that the DNA sequences obtained were closely related to the partial sequence of several Bacillus sp. with over
$99.91 \%$ similarity. Molecular phylogenetic studies using the neighbor joining method linked the identity of the obtained bacterium sequence to Bacillus safensis. Thus, this bacterium is tentatively assigned as Bacillus safensis Strain BUK_BCH_BTE6. The bacterial sequence was deposited in the GenBank with the accession number OK180490.1 


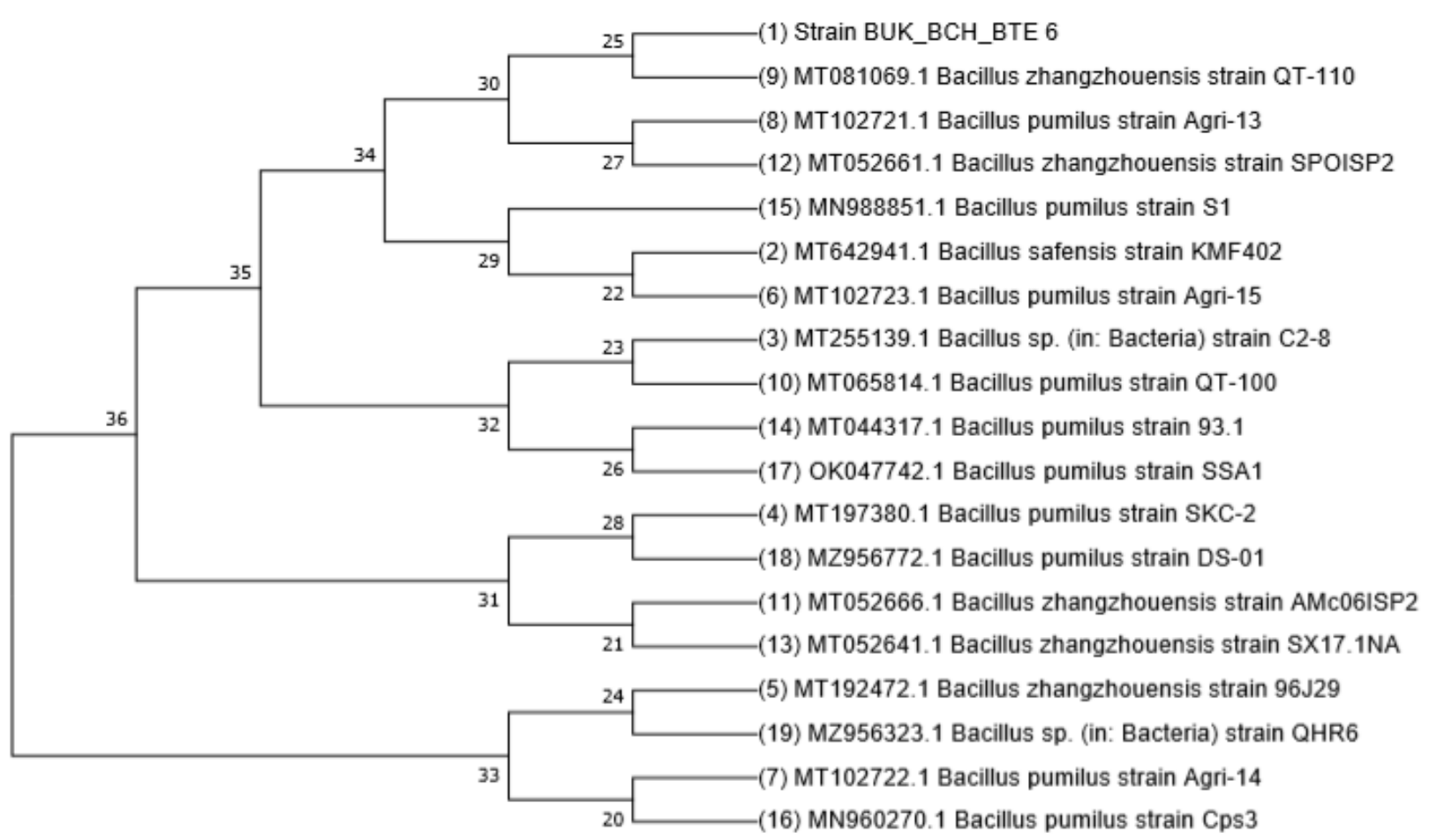

Figure 1: Cladogram (neighbor-joining method) indicating the genetic relationship between Bacillus safensis and reference related microorganisms based on 16S rRNA gene sequence. Species name are accompanied by the accession numbers of their 16s rRNA gene sequence. Numbers at the nodes indicate bootstrap values from the neighborhood-joining analysis of 1,000 resampled data sets.

\section{Characterization of Atrazine-degrading Bacteria using One Factor at a Time (OFAT)}

Several factors arising from the environment are known to affect the growth of microorganism. A triplicate experimental run was conducted using one factor at a time (OFAT) to study the effect of $\mathrm{pH}$ and Temperature for maximum atrazine growth using the bacterial strain.

Effect of initial $\mathrm{pH}$ on the growth of atrazinedegrading bacteria

The effect of various $\mathrm{pH}$ on the growth of atrazine-degrading Bacillus safensis on MSM media was presented in figure 2. It was found that growth of this bacterium tends to be optimum at $\mathrm{pH} 7.5$ following 48 hours' incubation at $37{ }^{\circ} \mathrm{C}$. A significant $(\mathrm{p}<0.05)$ decrease in growth was observed at $\mathrm{pH}$ higher than 7.5.
Statistical analysis showed a significant difference $(\mathrm{p}<0.05)$ between the $\mathrm{pH}$ values of $5.5,6.0,6.5$, 7.0, 7.5 and 8.0.

Effect of temperature on the growth of atrazinedegrading bacteria

The effect of various temperature on the growth of atrazine-degrading Bacillus safensis strain BUK_BCH_BTE6 on MSM media was presented in figure 3. It was found that growth of this bacterium tend to be optimum at $35^{\circ} \mathrm{C}$ following

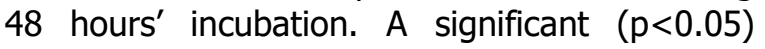
decrease in growth was observed at temperature higher than $40^{\circ} \mathrm{C}$. Statistical analysis showed a significant difference $(p<0.05)$ between the temperature of $25^{\circ} \mathrm{C}, 30^{\circ} \mathrm{C}, 35^{\circ} \mathrm{C}, 40^{\circ} \mathrm{C}, 45^{\circ} \mathrm{C}$ and $50^{\circ} \mathrm{C}$. 


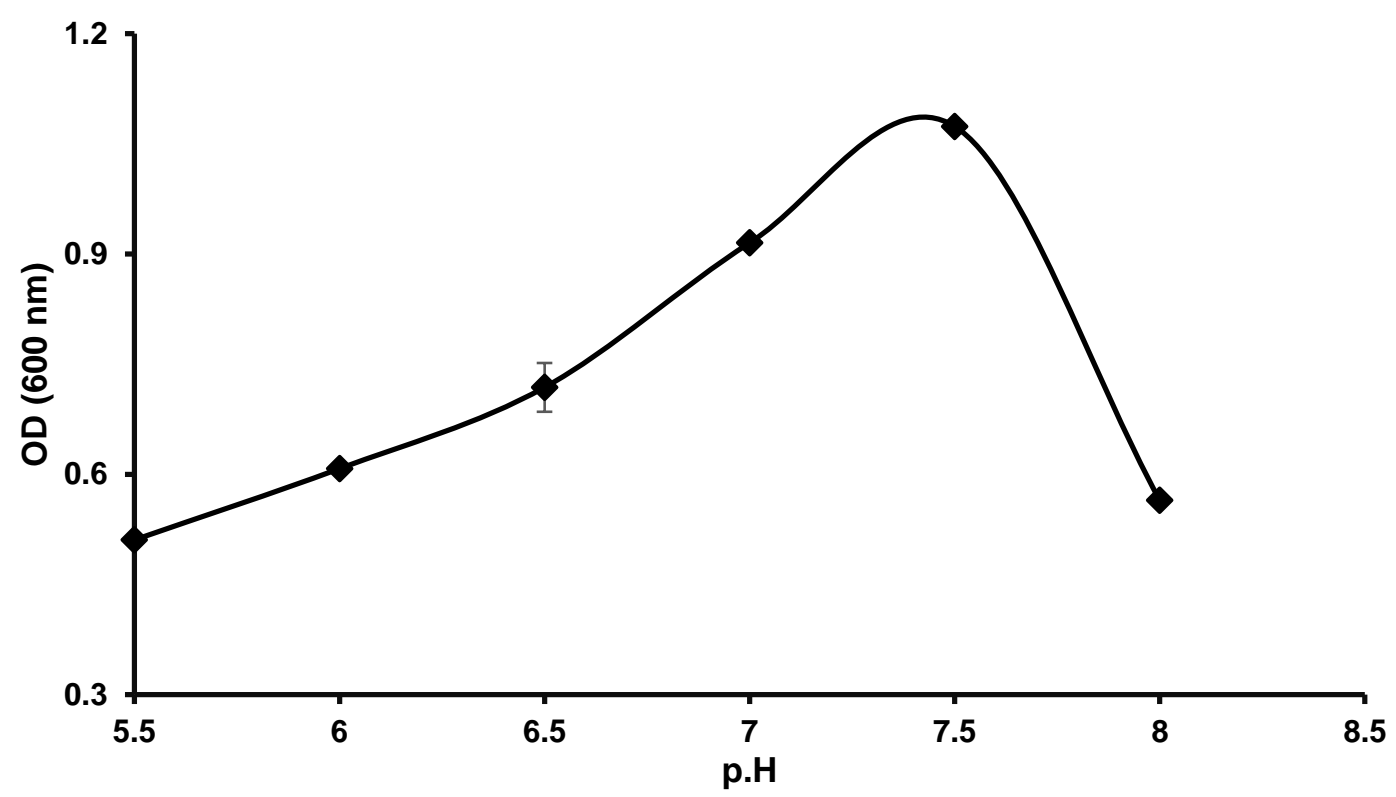

Figure 2: Effect of $\mathrm{pH}$ on the growth of atrazine-degrading Bacillus safensis strain BUK_BCH_BTE 6 in MSM media supplemented with $100 \mathrm{mgL}^{-1}$ initial atrazine, incubated for 48 hours at $37^{\circ} \mathrm{C}$. Data are mean \pm SD of triplicate determinations.

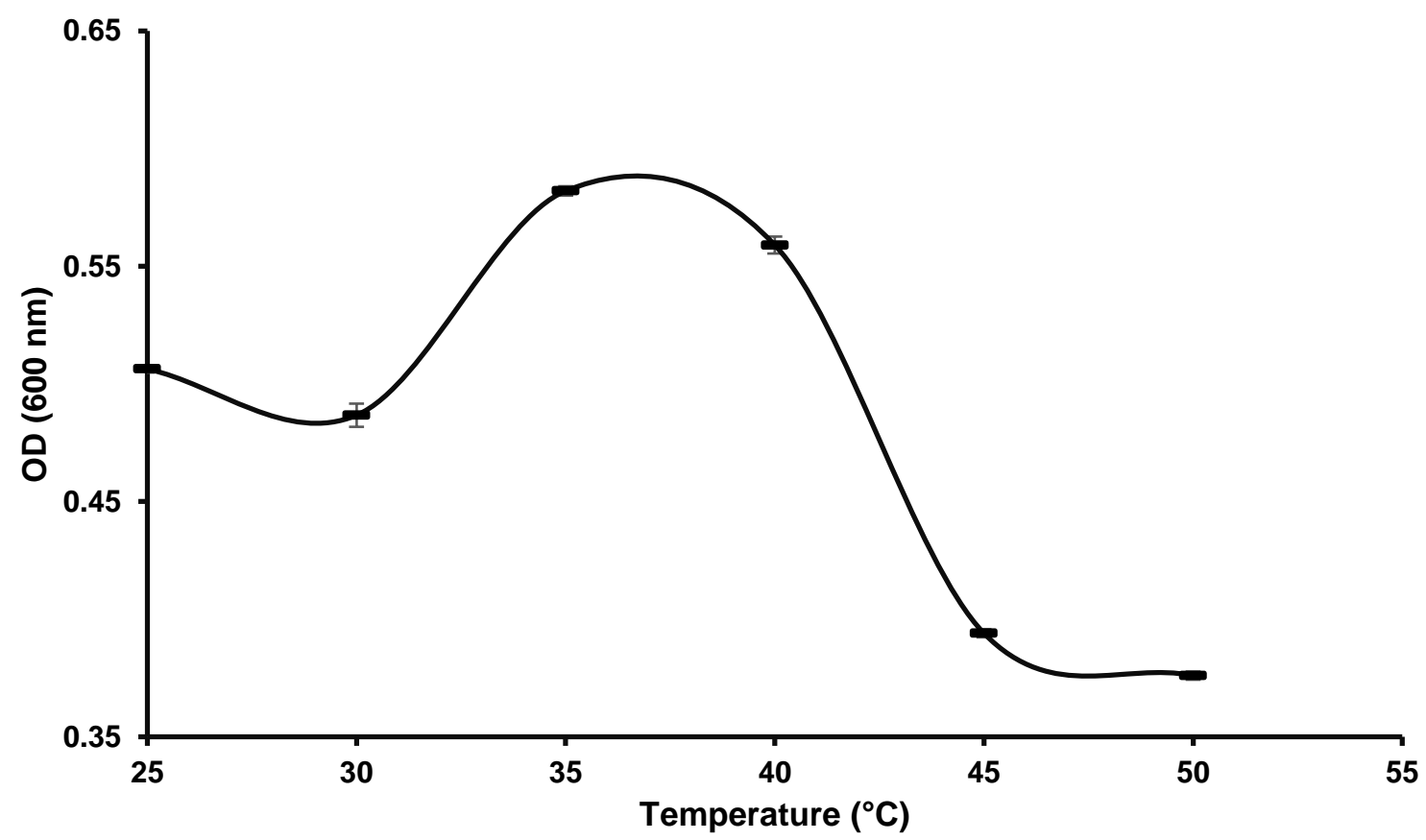

Figure 3: Effect temperature on the growth of atrazine-degrading Bacillus safensis strain BUK_BCH_BTE 6. in MSM media supplemented with $100 \mathrm{mgL}^{-1}$ initial atrazine, incubated for 48 hours at $37^{\circ} \mathrm{C}$. Data are mean \pm SD of triplicate determination. 


\section{Discussion}

There is a significant diversity in the genera of bacteria capable of degrading atrazine (Li et al., 2019). Based on this research, a bacterium with potential of atrazine degradation was isolated from agricultural soil and identified as Bacillus safensis strain BUK_BCH_BTE6 according to $16 \mathrm{~S}$ rRNA gene sequencing and molecular phylogeny. The bacterial sequence was deposited in the GenBank with the accession number OK180490.1

$\mathrm{pH}$ is among the most important parameters influencing the effectiveness of many chemical and biological activities (Shamsedini et al., 2016). The changes in values of $\mathrm{pH}$ affect both the structure and activity of protein, this also affects the activity of cellular enzymes. Drastic change in $\mathrm{pH}$ also damages the cell membrane and membrane proteins, which in turn debilitate permeability barrier of cell. The $\mathrm{pH}$ of the environment of the organism is frequently altered by metabolic activity of organism itself or by other activities in nature. This is implied when culture media are incorporated with buffers that can resist the change in $\mathrm{pH}$ (Cho et al., 2016). The effect of various $\mathrm{pH}$ on the growth of atrazinedegrading Bacillus safensis on MSM media was presented in Figure 2. It was found that growth of this bacterium tends to be optimum at $\mathrm{pH} 7.5$ following 48 hours' incubation at $37^{\circ} \mathrm{C}$. A significant $(p<0.05)$ decrease in growth was observed at $\mathrm{pH}$ higher than 7.5. Statistical analysis showed a significant difference $(p<0.05)$ between the $\mathrm{pH}$ values of $5.5,6.0,6.5,7.0,7.5$ and 8.0.

This rate is consistent with findings from similar studies Abigail et al (2013); Kolekar et al (2014); Wang et al (2014); Zhu et al (2019); Li et al (2019) and Khatoon and Rai (2020). This implies that $\mathrm{pH}$ plays a significant role in microbial metabolism and atrazine degradation is $\mathrm{pH}$ dependent (Andleeb et al., 2016).

All life processes leading to growth are catalyzed by the enzymes present in the cell. The activity of enzymes is influenced by temperature and therefore temperature is able to influence growth (Charpe et al., 2019). The effect of various temperature on the growth of atrazine-degrading Bacillus safensis on MSM media was presented in Figure 3. It was found that growth of this bacterium tend to be optimum at $37^{\circ} \mathrm{C}$ following 48 hours' incubation. A significant $(p<0.05)$ decrease in growth was observed at temperature higher than $40{ }^{\circ} \mathrm{C}$. Statistical analysis showed a significant difference $(p<0.05)$ between the temperature ranges of $25^{\circ} \mathrm{C}, 30^{\circ} \mathrm{C}, 35^{\circ} \mathrm{C}, 40$ ${ }^{\circ} \mathrm{C}, 45^{\circ} \mathrm{C}$ and $50^{\circ} \mathrm{C}$.

Similar results were obtained by Ariole and Abubakar (2015); Mansee et al (2017) and Zhao et al (2018). Growth and degradation abilities were both inhibited when the temperature was higher than $40^{\circ} \mathrm{C}$ or lower than $35^{\circ} \mathrm{C}$. This result indicate that the bacterium is mesophilic and that temperature have significant effect in bacterial physiological process and biodegradation of atrazine herbicide. The results also revealed that the optimal temperature of $35^{\circ} \mathrm{C}$ for atrazine degradation is close to the optimal growth temperature for Bacillus sp., which is $37^{\circ} \mathrm{C}$, this result is in agreement with that of Omotayo et al (2016). Results of this research prove the statement that the rate of microbial and chemical degradation are influenced by higher temperature and the rate at which pesticides dissipates is significantly faster under tropical conditions. As such, the overall degradation in tropical regions might be favorable than in temperate regions (Omotayo et al., 2016).

\section{Conclusion}

A bacterium with the ability to grow on and tolerate up to $1500 \mathrm{mgL}^{-1}$ of atrazine herbicide (as sole carbon source) was isolated from agricultural soil in Kura Local Government Area of Kano State, Nigeria. Morphological and biochemical identifications revealed the isolate as gram positive, rod shaped, which was identified as Bacillus safensis strain BUK_BCH_BTE6 based on $16 \mathrm{~S}$ rRNA gene sequencing and subsequent molecular phylogenetic analysis. Bacillus safensis has an optimum $\mathrm{pH}$ range of 7.5 and temperature of $35^{\circ} \mathrm{C}$. As such Bacillus safensis have great potential of atrazine-degradation and can be used as a suitable candidate for bioremediation of atrazine polluted sites.

\section{References}

Abigail, E. A., Salam, J. A., and Das, N. (2013). Atrazine Degradation in Liquid Culture and soil by a Novel Yeast Pichia kudriavzevii Strain AtzEN-01 and its Potential Application for Bioremediation. J. Appl. Pharmaceut. Sci, 3(06): 35-43. 
Andleeb, S., Jiang, Z., Rehman, K., Olajide, E. K., and Ying, Z. (2016). Direct Influence of Soil pH and Temperature on Atrazine Bioremediation. J. Northeast Agric. Uni, 23(2): 12-19.

Ariole, C. N., and Abubakar, A. (2015). Biodegradation of Atrazine by Bacteria Isolated from Lotic Water. J. Appl. Life Sci. Intl, 2(3): 119-125.

Ayodele, O. J. (2016). Economic Analysis of Irrigated Rice Production in Kura. Unpublished Msc Dissertation.

Charpe, A. M., Sedani, S. R., Murumkar, R. P., and Bhad, R. G. (2019). Effect of Temperature on Microbial Growth in Food During Storage. NAHEP, ICAR Sponsored, International Conference on Eares-2019, at Dr. PDKV Akola. ISSN 2277-7601.

Cho, S., Kim, M., and Lee, Y. (2016). Effect of pH on Soil Bacterial Diversity. J. Ecol. Environ, 40(10): 1-9.

He, H., Liu, Y., You, S., Liu, J., Xiao, H., and Tu, Z. (2019). A Review on Recent Treatment Technology for Herbicide Atrazine in Contaminated Environment. Int. J. Environ. Res. Public Health, 16(2019): 5129.

Izabel, M., Guedes, F., Florean, E. T., Lima, F., and Benjamin, S. R. (2020). Current Trends in Nanotechnology for Bioremediation. Int. J. Environ. Pollut, 66(1/2/3):19.

Khatoon, H., and Rai, J. P. N. (2020). Optimization Studies on Biodegradation of Atrazine by Bacillus badius ABP6 Strain Using Response Surface Methodology. Biotechnol. Rep, 26: e00459.

Kolekar, P. D., Phugare, S. S., and Jadhav, J. P. (2014). Biodegradation of Atrazine by Rhodococcus $s p$. $\mathrm{BCH} 2$ to $\mathrm{N}$-isopropylammelide with Subsequent Assessment of Toxicity of Biodegraded Metabolites. Environ. Sci. Pollut. Res, 21(3): 2334-2345.

Li, Y., Liang, D., Sha, J., Zhang, J., and Gao, J. (2019). Isolating and Identifying the AtrazineDegrading Strain Arthrobacter sp. LY-1 and Applying it for the Bioremediation of
Atrazine-Contaminated Soil. Pol. J. Environ. Stud, 28(3): 1267- 1275.

Macwilliams, M. P. (2016). Luria Broth ( LB ) and Luria Agar ( LA ) Media and Their Uses Protocol. Americasn Society of Microbiology, October 2006: 18-21.

Mansee, A. H., Bakry, N. M., and El-gwad, D. M. A. (2017). Factors Affecting Potentials of Certain Bacterial Isolates for Atrazine Bioremediation. Agric. Eng. Int, 91(2017): 91-100.

Olu-arotiowa, O., Ajani, A., Aremu, M. O., and Agarry, S. E. (2019). Bioremediation of Atrazine Herbicide Contaminated Soil Using Different Bioremediation Strategies. J. Appl. Sci. Environ. Manag, 23(1): 99-109.

Omotayo, A. E., Ilori, M. O., Obayori, O. S., and Oladipo, O. (2016). Influence of $\mathrm{pH}$, Temperature and Nutrient Addition on the Degradation of Atrazine by Nocardioides spp. Isolated from Agricultural Soil in Nigeria. Malays. J. Microbiol, 12(4): $270-278$.

Sawangjit, S. (2016). Isolation and Characterization of Atrazine-Degrading Xanthomonas sp. ARB2 and Its Use in Bioremediation of Contaminated Soils. Int. J. Environ. Sci. Dev, 7 (5): 351-354.

Sayara, T., and Sánchez, A. (2020). Bioremediation of PAH Contaminated Soils: Process Enhancement Through Composting/Compost. Appl. Sci, 10(3684): 1-20.

Shamsedini, N. (2015). Photodegradation of Atrazine by Ultraviolet Radiation in Different Conditions. Health scope, 3(3): 94-100.

Shiri, M. A. (2016). Isolation of Atrazine Degrading Bacteria in Semi Salinity Medium. J. Health Sci. Surveill. Syst, 4(3): 121-128.

Wang, J., Zhu, L., Wang, Q., Wang, J., and Xie, $\mathrm{H}$. (2014). Isolation and Characterization of Atrazine Mineralizing Bacillus subtilis Strain HB-6. Plos One, 9(9): 1-9.

Wang, H. (2015). Biodegradation of Arazine by Arthrobacter sp. C3, Isolated from the Herbicide 
Contaminated Corn Field. Intern. J. Environ. Sci. Tech, 13(2016): 257-262

Zhao, X., Wang, L., Ma, F., and Yang, J. (2018). Characterisation of an Efficient Atrazine Degrading Bacterium, Arthrobacter $s p$. ZXY-2:

An Attempt to Lay the Foundation for Potential Bioaugmentation Applications.

Biotechnol. Biofuels, 11(113): 1-10.

Zhao, X., Wang, L., Du, L., Yang, J., Donga J., and Ma, P. (2017). Optimization of Culturing Conditions for Isolated Arthrobacter sp. ZXY-2, An Effective Atrazine-Degrading and SaltAdaptive Bacterium. R. Soc. Chem, 7(2017): $\quad$ 33177-33184.

Zhu, J., Fu, L., Jin, C., Meng, Z., and Yang, N. (2019). Study on the Isolation of Two Atrazine Degrading Bacteria and the Development of a Microbial Agent. Microorganism, 7(80): 1-11. 